\title{
Functional State Assessment During Physical Education Classes By Experimental Method
}

\author{
D. E. Egorov \\ Department of physical education and sport \\ Belgorod State Technological \\ University named after V.G. Shukhov \\ Belgorod, Russia \\ fiz_dimon@mail.ru
}

\author{
S. I. Kramskoy \\ Department of physical education and sport \\ Belgorod State Technological \\ University named after V.G. Shukhov \\ Belgorod, Russia \\ si-kramskoy@yandex.ru
}

\author{
I. A. Amelchenko \\ Department of physical education and sport \\ Belgorod State Technological \\ University named after V.G. Shukhov \\ Belgorod, Russia \\ irinafiz@yandex.ru
}

\begin{abstract}
The paper analyses functional state indicators in the experimental and control groups obtained at the time of the studies. Data of maximum oxygen intake and results of the functional test are presented. The efficiency of the method, including a health-improving component for enhancing physical work capacity, is evaluated.
\end{abstract}

Keywords-physical work capacity, functional state, maximum oxygen intake, health, testing, methodology.

\section{INTRODUCTION}

The faculty of the Department of Physical Education faces a task of systematical improvement of the work on making students healthier. The realm of issues covering implementation of a health-forming program includes consolidation of material and financial resources, development of forms of work in the field of physical training and sport [1]. BSTU named after V.G. Shukhov uses the following forms of organization of health and fitness activities: general physical training, special physical training, diverse sports leagues (bodybuilding, shaping, athletics, table tennis, boxing, kickboxing, competitive skiing, swimming, water polo, etc.), health groups [2]. The principal form of organization of the physical education is a practical training, during which an instructor performs tasks to reach predefined objectives. The tasks are performed within a program based upon cyclic kinds of sports and muscle-strengthening aerobics, taking into account climatic conditions [3, 4]. The study of indicators of cardiorespiratory changes under the influence of physical training in different environments allows revealing features of adaptive reactions, evaluating the degree of influence of the physical training on the organism as a whole and offering practical recommendations on planning health and fitness programs [5-9].

\section{ORGANISATION, PHASES AND TECHNIQUE OF RESEARCH}

\section{Research organisation}

A distinctive feature of the approved program of physical training lessons was running exercises at the first class of the week and performing the sets of muscle-strengthening aerobics "pump" at the second class. The running exercises were performed outdoors. The muscle-strengthening aerobics took place in a gym throughout the entire academic year. Each re- sistance-based exercise class included the following exercises: bench pressing, front squat, thigh-developing exercises, including different exercises to develop abs, back and neck muscles. The work intensity corresponded to a pulse mode of 140150 beats per minute. The weight was adjusted individually with considerations of the degree of physical fitness and was in the ranges of 5-10 and 15-18 $\mathrm{kg}$ for presses and squats respectively.

The running exercises were performed in groups, load exercises were performed as a continuous exercise. The amount and intensity of the running exercise were adjusted individually, with the monitoring of the heart rate before exercising ( $67 \pm 1.5)$, during exercising $(126 \pm 2.9)$ and after exercising $(88 \pm 3)$.

\section{Phases of the training process}

The following experimental scheme of the physical education training process was proposed with considerations of semesters:

\section{Phase 1 - Involving (September 1 - October 1).}

Objectives:

1. Assessment of the baseline of physical development, physical training and physical working capacity.

2. Improvement of coordination of movements and strength endurance.

3. Improvement of basic physique.

4. Study and improvement of the running technique, learning the sets of load exercise. Consolidation of the locomotor apparatus.

Means:

- Running exercises of uniform intensity, the periodic monitoring of pulse (mode: 130-140 beats per minute).

- Jogging (2000-3000 m) or jogging alternated with walking (3000-5000 m).

- General development exercises.

- Load exercises, the periodic monitoring of pulse (mode: $140-150$ beats per minute). 
- Sport games (football (soccer), lapta).

Phase 2 - Developing (October 1 - December 30).

Objectives:

1. Evaluation of physical training and physical work capacity.

2. Development of strength endurance.

3. Improvement of basic physique.

4. Improvement of the technique in running and load exercises. Studying rules and tactics of lapta, football, basketball.

\section{Means:}

- Running exercises in a uniform tempo, the periodic monitoring of heart rate (140-150 beats per minute).

- Cross-country running (2000-3000 m) at a heart rate of 130-150 bpm.

- Load exercises aimed at development of the main muscle groups at a heart rate of 140-150 bpm.

- Sport games (football (soccer), lapta).

Phase 3 - Regenerative and supportive (February 1 March 15).

\section{Objectives:}

1. Determination of the level of fitness and physical work capacity (after the winter vacations).

2. Study and improvement of the ski running technique and load exercises technique.

3. Improvement of functional training.

4. Development of strength endurance of the muscle groups that work while sitting.

\section{Means:}

- Ski running with a uniform intensity at a heart rate of 150 $\pm 10 \mathrm{bpm}$.

- Load exercises are performed at a heart rate of 140-150 bpm, aimed at development of the muscle groups working while sitting.

- Sport games (football (soccer), lapta).

Phase 4-Developing (March 16 - May 1).

\section{Objectives:}

1. Evaluation of physical fitness and physical working capacity.

2. Improvement of functional training.

3. Development of general and strength endurance.

4. Improvement of the technique in running and load exercises. Preparation for taking the credit tests and standards.

\section{Means:}

- Running with a uniform intensity at a heart rate of 150 $160 \mathrm{bpm}$.
- Cross-country running (2000-3000 m) at a heart rate of 150-160 bpm

- General developing exercises.

- Load exercises are performed at a heart rate of 150-160 bpm, aimed at development of the muscle groups working while sitting.

- Sport games (football (soccer), lapta).

- Jumping exercises.

Phase 5 - Special (May).

\section{Objectives:}

1. Determination of the final training level, growth in physical fitness and physical working capacity gained at the end of the academic year.

2. Further improvement of functional possibilities and development of physical qualities. Credit tests and standards passing procedure.

Means:

- Running with a uniform intensity at a heart rate of 160 $170 \mathrm{bpm}$.

- Cross-country running (2000-3000 m) at a heart rate of 160-170 bpm.

- Jumping exercises.

- General developing exercises.

- Resistance exercises at a heart rate of 160-170 bpm, aimed at elimination of negative consequences resulted from prolonged sitting, enhancement of strength endurance.

- Sport games (football (soccer), lapta).

The objectives of assessment of an initial physical fitness level, improvement of general physical fitness, development of general and strength endurance, improvement of running technique and load exercises technique were consistently tackled at all the phases. Sport games were used as a mean of regeneration and changing the type of motor activity. The total running distance during the academic year amounted to $330 \pm$ $10 \mathrm{~km}$. Intensity of the running exercise never exceeded that of a heart rate of 160-170 bpm. The load exercises included 10-20 repeatitions per series and 4-5 series in total.

\section{Research Methodology}

According to V.L. Karpman [5], the Maximum Oxygen Intake (MOI) amount is an integral indicator of a functional state of an organism, which characterizes the general physical working capacity of a person to a reasonable degree. The MOI level shows high correlation with the results in cyclic kinds of exercises (long-distance running, power walking, competitive skiing etc). In persons having diseases of the circulatory system, the individual value of MOI reflects their state (so-called functional class) and thus is taken into account when clarifying a diagnosis, giving prognosis, as well as for evaluation of medical and preventive measures efficiency[10-12]. According to the same sources, World Health Organization (WHO) treats determination of MOI as the most reliable method to 
assess person's physical working capacity.

Due to high significance of the MOI level in evaluation of physical work capacity, it was used for the functional monitoring of the trial subjects. The MOI level was calculated indirectly from the following linear equation:

$$
\mathrm{MOI}=1.7 \times \mathrm{PWC}_{170}+1240
$$

The MOI levels were evaluated according to the table proposed by V.L. Karpman [5, 6].

The physical working capacity was determined with a $\mathrm{PWC}_{170}$ test. This indicator reflects the efficiency of the circulation system performance and functional systems of the organism. As the absolute values of $\mathrm{PWC}_{170}$ are highly correlated with the body size, a relative value of $\mathrm{PWC}_{170}$ is calculated as a value per 1 kilogram of the body weight. The results obtained were evaluated using the table $[1,13]$.

\section{RESULTS AND DISCUSSION}

To increase efficiency of different types of sports activities and first and foremost that of the health-improving component, it is necessary to determine the reaction of the organism to the exercise and reveal any pathological processes $[14,15]$. That is why a functional testing was included into the research.

The data, obtained from testing the control and experimental groups to determine the MOI value, are given in Tables 1 and 2.

There were no results matching the "very low" level neither in control, nor in experimental groups, neither at the beginning, not at the end of the experiment.

TABLE I. LEVEL OF MOI DEVELOPMENT IN GIRLS

\begin{tabular}{|c|c|c|c|c|}
\hline \multirow{3}{*}{$\begin{array}{c}\text { Statistical } \\
\text { category }\end{array}$} & \multicolumn{2}{|c|}{ Control group } & \multicolumn{2}{|c|}{ Experimental group } \\
\hline & $\begin{array}{c}\text { Experi- } \\
\text { ment start }\end{array}$ & $\begin{array}{l}\text { Experi- } \\
\text { ment end }\end{array}$ & $\begin{array}{c}\text { Experi- } \\
\text { ment start }\end{array}$ & $\begin{array}{c}\text { Experiment } \\
\text { end }\end{array}$ \\
\hline & $\mathrm{ml} / \mathrm{min}$ & $\mathrm{ml} / \mathrm{min}$ & $\mathrm{ml} / \mathrm{min}$ & $\mathrm{ml} / \mathrm{min}$ \\
\hline $\mathrm{X}$ & 2090.85 & 2158.286 & 2069.88 & 2421.47 \\
\hline St.error & 42.74 & 43.66791 & 34.077 & 25.52 \\
\hline $\begin{array}{l}\text { St. devia- } \\
\text { tion }\end{array}$ & 222.1 & 226.9051 & 177.07 & 132.6 \\
\hline${ }^{ \pm} \sigma$ & 197.625 & 205.275 & 133.875 & 120.7 \\
\hline$\pm \mathrm{m}$ & 38.03 & 39.51 & 25.76 & 23.2287 \\
\hline
\end{tabular}

TABLE II. ASSESSMENT OF CHANGES IN MOI LEVEL

\begin{tabular}{|c|c|c|c|c|}
\hline \multirow{2}{*}{$\begin{array}{c}\text { Eval- } \\
\text { uation }\end{array}$} & \multicolumn{2}{|l|}{ Control } & \multicolumn{2}{|c|}{ Experimental } \\
\hline & $\begin{array}{c}\text { Experiment } \\
\text { start }\end{array}$ & $\begin{array}{l}\text { Experiment } \\
\text { end }\end{array}$ & $\begin{array}{c}\text { Experiment } \\
\text { start }\end{array}$ & $\begin{array}{l}\text { Experiment } \\
\text { end }\end{array}$ \\
\hline $\begin{array}{l}\text { very } \\
\text { low }\end{array}$ & $0 \%$ & $0 \%$ & $0 \%$ & $0 \%$ \\
\hline low & $7 \%$ & $0 \%$ & $7 \%$ & $0 \%$ \\
\hline $\begin{array}{l}\text { aver- } \\
\text { age }\end{array}$ & $33 \%$ & $30 \%$ & $45 \%$ & $4 \%$ \\
\hline high & $38 \%$ & $30 \%$ & $26 \%$ & $26 \%$ \\
\hline $\begin{array}{l}\text { very } \\
\text { high }\end{array}$ & $22 \%$ & $40 \%$ & $22 \%$ & $70 \%$ \\
\hline
\end{tabular}

Table 1 shows the percentage ratios of testees with different MOI levels assessed according to Table 2.

The results corresponding to the "low" level were registered for $7 \%$ of students at the beginning of the experiment; no students showed this level at the end of the experiment. The average level of MOI development was registered for $33 \%$ of students in the control group, while at the end of the experiment this level was shown by $30 \%$ of students. In the experimental group, the share of the average level dropped from $45 \%$ to $4 \%$. At the beginning of the experiment and after it, the share of the "high" level participants remained the same at $26 \%$. The control group showed a drop in this category from $38 \%$ at the beginning to $30 \%$ at the end of the experiment. By the moment of the MOI testing, there was an increase in the number of students with "very high" level results in the experimental group, from $22 \%$ in the beginning of the experiment to $70 \%$ at the end of the experiment. The control group shows a weaker growth (18\%) in the number of female students having the "very high" level - from $22 \%$ to $40 \%$ of students at the end of the experiment.

Analysis of the changes in the MOI level shows that there is a trend for higher growth in the number of students in the experimental group, where the "very high" level was achieved by additional 48 percent of students, while in the control group this growth is less pronounced and is limited to $18 \%$. This trend was created owing to lowering the number of students with lower MOI development values, and it amounted to 1.111 $\mathrm{kgm} / \mathrm{min} / \mathrm{kg}$ in relative units. There are also higher quantitative and qualitative indicators in the experimental group (Table 4). No students achieved the "high" level, neither in the control nor in the experimental group. A higher dynamics is noted for the students of the experimental group with the results in the "above average" category, from $0 \%$ in the beginning of the experiment - to $26 \%$ after the experiment. The number of students with this indicator in the control group is stable at $4 \%$ before and after the experiment. The experimental group also shows a more significant increase (from $22 \%$ to $70 \%$ ) in students showing "average"results, while in the control group, the number of students with this type of results stayed the same at 37\% (Table 4). The experimental group shows a decline in the number of students with the results in categories "average" and "above average". There is a drop in the number of students in the "below average" category from $37 \%$ to $4 \%$, while in the control group there is an increase in the number of students in the "below average" category from 
$15 \%$ to $26 \%$. There is a reduction in the number of students showing results pertaining to the "low" level in both control and experimental groups, from $44 \%$ to $33 \%$ and from $41 \%$ to $0 \%$ respectively.

TABLE III. LEVELS OF PHYSICAL WORKING CAPACITY DEVELOPMENT ACCORDING TO PWC $_{170}$ TEST

\begin{tabular}{|c|c|c|c|c|c|c|c|c|}
\hline & $\begin{array}{c}\text { PW } \\
\mathrm{C}_{170} \\
\text { kgm/ } \\
\text { min }\end{array}$ & $\begin{array}{c}\mathrm{PW} \\
\mathrm{C}_{170} \\
\mathrm{kgm} / \\
\mathrm{min} / \\
\mathrm{kg}\end{array}$ & $\begin{array}{c}\mathrm{PW} \\
\mathrm{C}_{170} \\
\mathbf{k g m} / \\
\mathrm{min}\end{array}$ & $\begin{array}{c}\text { PW } \\
\mathrm{C}_{170} \\
\mathrm{kgm} / \\
\mathrm{min} / \\
\mathrm{kg}\end{array}$ & $\begin{array}{c}\mathrm{PW} \\
\mathrm{C}_{170} \\
\mathbf{k g m} / \\
\mathrm{min}\end{array}$ & $\begin{array}{c}\mathrm{PW} \\
\mathrm{C}_{170} \\
\mathbf{k g m} / \\
\mathrm{min}\end{array}$ & $\begin{array}{c}\mathrm{PW} \\
\mathrm{C}_{170} \\
\mathrm{kgm} / \\
\mathrm{min} / \\
\mathrm{kg}\end{array}$ & $\begin{array}{c}\mathrm{PW} \\
\mathrm{C}_{170} \\
\mathrm{kgm} / \\
\mathrm{min} / \\
\mathrm{kg}\end{array}$ \\
\hline $\mathrm{X}$ & 488.2 & 9.2 & 695 & 13.6 & 500.5 & 540.2 & 9.41 & 10.521 \\
\hline $\begin{array}{c}\text { St.err } \\
\text { or }\end{array}$ & 20.1 & 0.4 & 15 & 0.4 & 25.14 & 25.7 & 0.5 & 0.52 \\
\hline $\begin{array}{c}\text { St. } \\
\text { devi- } \\
\text { ation }\end{array}$ & 104.2 & 2.22 & 78.0 & 2.12 & 130.65 & 133.5 & 2.6 & 2.7 \\
\hline$\pm \sigma$ & 78.75 & 1.9 & 71 & 2 & 116.25 & 120.75 & 2 & 2.15 \\
\hline$\pm \mathrm{m}$ & 15.16 & 0.4 & 13.7 & 0.4 & 22.37 & 23.24 & 0.4 & 0.41 \\
\hline
\end{tabular}

In the control group, the number of students with the high level reduced $(-8 \%)$, while there were no changes in the number of students at this level in the experimental group (Table $2)$. The number of the students with the average level decreased $(-3 \%)$, while in the experimental group there were more significant changes at $41 \%$. The same changes in the number of students matching the low level of the test $(-7 \%)$ happened in both groups; the number dropped from $7 \%$ to $0 \%$ in both groups. The authors relates more significant changes in MOI development in the experimental group to a greater number of cyclic kinds of exercises and muscle-strengthening aerobics.

The physical working capacity was evaluated by the analysis of dynamics of $\mathrm{PWC}_{170}$ results and comparison of the data obtained with the normal values of $\mathrm{PWC}_{170}$ for the age group being tested. Despite the higher initial level of $\mathrm{PWC}_{170}$, values in the control group at the beginning of the experiment, both in absolute and relative numbers (Table 3,4), after the experiment, there are higher levels in the experimental group (Table $3,4)$. In the experimental group, the increment of the physical working capacity in absolute $P W C_{170}$ values amounted to $206.8 \mathrm{kgm} / \mathrm{min}$, and in relative figures $-4.4 \mathrm{kgm} / \mathrm{min} / \mathrm{kg}$, while in the control group the increment is significantly lower and reaches $39.7 \mathrm{kgm} / \mathrm{min}$ in absolute numbers.

TABLE IV. PHYSICAL WORKING CAPACITY DEVELOPMENT ACCORDING TO PWC170 TEST

\begin{tabular}{|c|c|c|c|c|c|c|}
\hline Groups & Periods & Low & $\begin{array}{c}\text { Below } \\
\text { average }\end{array}$ & Average & $\begin{array}{c}\text { Above } \\
\text { average }\end{array}$ & High \\
\hline \multirow[b]{2}{*}{ Experimental } & $\begin{array}{c}\text { Experiment } \\
\text { start }\end{array}$ & $41 \%$ & $37 \%$ & $22 \%$ & $0 \%$ & $0 \%$ \\
\hline & $\begin{array}{c}\text { Experiment } \\
\text { end }\end{array}$ & $0 \%$ & $4 \%$ & $70 \%$ & $26 \%$ & $0 \%$ \\
\hline \multirow{2}{*}{ Control } & $\begin{array}{c}\text { Experiment } \\
\text { start }\end{array}$ & $44 \%$ & $15 \%$ & $37 \%$ & $4 \%$ & $0 \%$ \\
\hline & $\begin{array}{c}\text { Experiment } \\
\text { end }\end{array}$ & $33 \%$ & $26 \%$ & $37 \%$ & $4 \%$ & $0 \%$ \\
\hline
\end{tabular}

\section{PRACTICAL CONSIDERATIONS}

Development and application of a science-based technique of application of muscle-strengthening aerobics and cyclic kinds of sports (running and competitive skiing exercises) will facilitate improvement in efficiency of the academic process, elimination of negative developments arising due to peculiarities of the academic process. It will help to improve physical state and to promote health. Considerations of climatic conditions of a region are necessary while planning motor activities and load scheduling.

\section{Acknowledgment}

The article was prepared with financial support for implementing the state assignment № 27.4338.2017/5.1 for the project execution on the subject «Studying the measures for involving students into the supplementary physical culture and sports education and for implementing the activities, aimed at promoting the Russian national physical culture and sports complex "Ready for Labor and Defense"»

\section{References}

[1] V.L. Karpman, Z.B. Belotserkovsky, I.A Gudkov, Testing In The Practice Of Sports, Moscow, Fizkultura i Sport, 1988, p. 20-27. (in Russian).

[2] Kramskoy S.I, Amelchenko I.A. From experience of implementing healthsaving technologies in BSTU named after V.G. Shoukhov // Zdorovye, Sport, Reabilitatsiya, Kharkiv, no. 3, 2016

[3] S.V. Kakhanovich, A.A. Shankin, K.V. Izvekov, "Regional aspects in adaptation of students to physical exercises," Teoria i praktika fizicheskoy kultury, No. 10, pp. 27-29, 2014.

[4] S.I. Kramskoy, I.A. Amelchenko, "Of the implementation of healthimproving program in conditions of technical university,"The higher education in Russia (educational research journal), No. 3, pp. 94-96, 2014.

[5] E.A. Bondar, I.A. Amelchenko, N.A. Tulinova, "Monitoring of functional state of special studies department students," Diskurs, vol. 1 (1), pp. 18- 23, 2016.

[6] V.I. Bondin, T.A. Zhabrova, "Adaptive changes in cardiorespiratory system of students under the influence of physical training in different environmental conditions," Teoria i Praktika Fizicheskoy Kultury, No. 12, pp. 52-54, 2016. (in Russian).

[7] G.A. Gilev, S.K. Romanovsky "Physical and functional preparedness of special medical group students and general medical group students," Kultura fizicheskaya i zdorovye, vol. 55, No. 4, pp. 84-89, 2015. (in Russian).

[8] M.V. Kovalyova, "Measured health-improving walking and running as a mean to correct state of cardio-resporatory system of tertiary education students," Nauka, obrazovaniye, obschestvo, Tambov, No. 1 (7), pp. 115-123, 2016.

[9] E. N. Kopeykina, V.V. Drogomeretsky, V. L. Kondakov, M. V. Kovalyova, S. S. Yermakov "Modification of Harvard Step Test to assess functional possibilities of students with substandard health," Fizicheskoye vospitaniye studentov. - Kharkiv, KSADA, 2016, no. 4, p. 44-51.

[10] V. A. Kurashvili Testing Sportsmen in Standard Laboratory Conditions, Vestnik Sportivnykh Innovatsiy, No. 53, p. 1-22, 2017.

[11] Samokish I.I. "Physical work capacity as a basis of functional possibilities of student youth," Fizicheskoye vospitaniye studentov, Kharkiv, KSADA, No. 6 , p. 40-48, 2016.

[12] I. B. Ulitin, V. G. .Kuzmin, B. I.. Ulitin, E. D. Pyatov, E. A.. Orlova, "Modern Approaches to evaluation of functional state of a sportsman," Kultura fizicheskaya i zdorovye, vol. 62, No. 2, p. 34-39, 2017.

[13] Sports Medicine / Edited by V.L. Karpman. Moscow: FiS, 1987, p. 88-131.

[14] D. E. Yegorov, N. B. Kutergin, I. V. Kulikova, "Dynamics and causes of students morbidity," Nauka. Iskusstvo. Kultura. No. 2 (10), Belgorod, BSIAC, p. 146-151, 2016.

[15] V. L. Kondakov, E. N. Kopeykina, A. N. Usatov, "On practicability of use of physical training and health-improving technology for prevention of respiratory health problems in students," Fizicheskoye vospitaniye studentov. - Kharkiv, KSADA, No. 2, p. 4-12, 2016. 